\title{
Dilemmas of Counter-Mapping Community Resources in Tanzania
}

\author{
Dorothy L. Hodgson and Richard A. Schroeder
}

\begin{abstract}
Recent work has celebrated the political potential of 'counter-mapping', that is, mapping against dominant power structures, to further seemingly progressive goals. This article briefly reviews the counter-mapping literature, and compares four counter-mapping projects from Maasai areas in Tanzania to explore some potential pitfalls in such efforts. The cases, which involve community-based initiatives led by a church-based NGO, ecotourism companies, the Tanzanian National Parks Authority, and grassroots pastoralist rights advocacy groups, illustrate the broad range of activities grouped under the heading of counter-mapping. They also present a series of political dilemmas that are typical of many counter-mapping efforts: conflicts inherent in conservation efforts involving territorialization, privatization, integration and indigenization; problems associated with the theory and practice of 'community-level' political engagement; the need to combine mapping efforts with broader legal and political strategies; and critical questions involving the agency of 'external' actors such as conservation and development donors, the state and private business interests.
\end{abstract}

\section{INTRODUCTION}

The recent dramatic resurgence of the community scale as the central organizing principle of natural resource management and the simultaneous emergence of powerful and relatively accessible mapping and spatial analysis technologies have given rise to a wide range of popular resource mapping exercises worldwide. These efforts, sometimes called 'counter-mapping'

The authors' names appear in alphabetical order; we have shared equally in the conceptualization and writing of this article. Research and writing have been supported by the Wenner Gren Foundation for Anthropological Research (Hodgson) and separate grants from the Faculty Research Council at Rutgers University and the Association of American Geographers (Hodgson, Schroeder). We would like to thank the Maasai activists and other Tanzanians who have helped us with this project, and the Tanzanian Commission for Science and Technology for permission to carry out the research. Finally, we are grateful to Tom Bassett, Fiona MacKenzie, Celia Nyamweru, Dave Peterson, Tom Spear, Kevin St. Martin, and two anonymous reviewers who provided helpful comments on earlier drafts.

Development and Change Vol. 33 (2002), 79-100. (C) Institute of Social Studies 2002. Published by Blackwell Publishers, 108 Cowley Road, Oxford OX4 1JF, UK. 
(Peluso, 1995) due to their intent of countering dominant representations of property regimes and land use practices, have opened up new political ecological terrain on which struggles over resources are linked to fundamental questions of culture, identity and power.

The prospects for counter-mapping with popular political movements and community groups have been touted in such diverse places as South Africa, South America and the South Bronx. In South Africa, the use of Geographical Information Systems (GIS) technology has been proposed as a way of re-writing the maps of apartheid (Harris et al., 1995). In South America, Global Positioning Systems (GPS) relying on satellite-based links have been used to help Amerindian groups stake formal claim to historical territories (Poole, 1995a). In the South Bronx, GIS databases documenting connections between the location of waste transfer stations and incinerators and disproportionately high rates of asthma and other airborne disease have graphically depicted the environmental injustices wrought against the residents of American inner cities (Maantay, 1996).

In addition to these decidedly high-tech approaches to mapping, activists and scholars have also turned to simple sketch mapping techniques, rapid rural appraisals, scale model construction and felt boards as means of eliciting and then representing the popular cartographies of particular groups (Poole, 1995a; Rocheleau, 1997; Rocheleau and Edmunds, 1997; Rocheleau et al., 1995). Thus, while much of the excitement surrounding counter-mapping is due to the emergence of newer technologies, the practice of counter-mapping has also drawn heavily on approaches that are far less costly and arguably more accessible in a wider range of circumstances.

The purposes of these various counter-mapping efforts are, if anything, even more diverse than the methods employed. Peter Poole, one of the best known practitioners and advocates of counter-mapping techniques, suggests that counter-maps can serve several critical functions in addressing the related problems of protecting indigenous land rights and maintaining high levels of biodiversity. These include, but are not limited to, the following: 1) gaining recognition of land rights; 2) demarcation of traditional territories; 3) protection of demarcated lands; 4) gathering and guarding traditional knowledge; 5) management of traditional lands and resources; and 6) community awareness, mobilization and conflict resolution (Poole, 1995b; see for example Eghenter, 2000; Hughes, 1999; Peluso, 1995; Poole, 1995a; Sirait et al., 1994; Sparke, 1998; St. Martin, 2001). Other objectives include providing baseline geographic and health data for future comparisons (Nietschmann, 1995), protecting and promoting cultural diversity (Gonzalez et al., 1995), and fostering community reunification and self-empowerment (Arvelo-Jiménez and Conn, 1995).

Numerous scholars and activists, including the many contributors to Poole (1995a), have celebrated the potential of counter-mapping for meeting ostensibly progressive political goals. Indeed, some have made elaborate claims on behalf of counter-mapping practices: 
Until recently, almost all maps were made by invading and occupying powers; however, this is rapidly changing as indigenous peoples are making and distributing their own maps using new technology that is much less expensive and much more accurate than the old technology that was once totally controlled by the map-making powers who used to lay claim to indigenous nations, lands and waters.... If it is well-designed, that map will have transcendental powers because it can easily be translated by everyone everywhere; it transcends literacy; it is visually comprehensible; it can be a more powerful national symbol than a flag or an anthem; its creation reinforces group cohesion ... and it provides strong credibility to its producers. (Nietschmann, 1995: 37)

Others, however, have been more measured in their assessment of the potential of counter-mapping efforts. For example, Dianne Rocheleau, one of the major proponents of efforts to 'map against power', ${ }^{1}$ has raised a number of critical questions regarding what she calls the 'new mania for mapping within social movements'. While she acknowledges that countermapping initiatives "can buy time and create space against the onslaught of mass eviction, wholesale land alienation and widespread despoliation by "outside" interests', she nonetheless maintains that 'they can also create whole territories, new terrains of "nature" and "culture" [and render them] available to the calculus of political and economic power as exchangeable and interchangeable units' (Rocheleau, 1997: 3, emphasis added).

Rocheleau is one of several scholars and activists who have critically analysed counter-mapping efforts. In her original contribution to this debate, Nancy Peluso stressed:

The key theoretical questions about the impacts of counter-mapping on resource control are to what degree new notions of territoriality reflect older ones; how the reinvention of these traditions benefits or works to the detriment of customary practice, law and resource distribution; and how the interventions of NGOs ... affect the villagers' access to and control over ... resources. (Peluso, 1995: 393)

Other issues that have been noted include the problem of translating local maps or cognitive categories into conventional cartographic maps (Fox, 1998; Rundstrom, 1995). Here, critiques centre on the over-reliance on discrete boundaries in the context of overlapping and often ambiguous tenure claims (Hughes, 1999; Walker and Peters, 2001); the disconnection between mapping scales and the scales at which community property relations and tenure claims are worked out (Eghenter, 2000; St. Martin, 2001); and the reliance of many counter-mapping projects on a bounded, simplistic idea of 'community' (Kosek, 1998). The latter concern begs a series of questions regarding the political dimensions of mapping efforts. These include the tendency to overlook and thus discredit the knowledge and property claims of women, minorities and other vulnerable and disenfranchised groups (Rocheleau and Edmunds, 1997; Schroeder 1999b), the potential for creating or exacerbating

1. Rocheleau was one of several scholars and activists, including Marcus Colchester, Nancy Lee Peluso and Peter Poole, who discussed this theme in 1996 at a conference titled 'Representing Communities: History and Practice of Community Resource Management' (Brosius et al., 1998). 
conflicts within or among communities (Eghenter, 2000; Fox, 1998), and, at a very basic level, the failure to acknowledge the inherently political nature of the involvement of outsiders (such as researchers or NGOs) in the mapping process (Kosek, 1998).

This article builds on and contributes to this prior work by exploring what we perceive to be some of the critical dilemmas of counter-mapping. To do so, the article analyses four mapping projects that have emerged in predominantly Maasai ${ }^{2}$ areas in Tanzania since the mid-1980s. The first, a village survey and land registration campaign initiated in 1985 by Maasai activists with the support of the Arusha Diocesan Development Office (ADDO), ${ }^{3}$ sought to establish legal boundaries around non-nucleated rural Maasai communities as a means of clarifying community-level tenure claims. The second, the Tarangire Conservation Project, was part of an outreach effort co-ordinated by the Tanzanian National Parks Authority to improve relations between Tarangire Park and its neighbours. A key component of the project involved encouraging residents in a de facto buffer zone surrounding the park to map their resources and land use practices. These findings were then to be incorporated into a Geographical Information Systems (GIS) database which would be available for community use. The third involved joint agreements between rural communities and private tour operators to create non-consumptive wildlife management areas on community lands. The fourth encompassed a series of proposals developed by Maasai NGOs and community groups for the creation of 'pastoralist reserves'. These groups advocated setting aside land for the exclusive use of pastoralists in areas where land use pressure was particularly intense.

The cases illustrate the broad range of activities grouped under the heading of counter-mapping. As such they also reflect the political dilemmas that are typical of many counter-mapping efforts: conflicts inherent in conservation efforts involving territorialization, privatization, integration and indigenization; problems associated with the theory and practice of 'community-level' political engagement; the limited scope of two-dimensional mapping tools; the need to combine mapping efforts with broader legal and political strategies; and critical questions involving the agency of 'external' actors such as conservation and development donors, the state and private business interests.

\section{BACKGROUND}

In order to understand some of the tensions surrounding these communitymapping cases, a brief history of Maasai cultural, political and economic

2. Where possible we use the accepted spelling 'Maasai', although 'Masai' is retained when used by others in historical documents and names such as 'Masai District'.

3. Dorothy Hodgson worked for ADDO from 1985 until 1987, and was the agency's director when some of the land registration efforts took place. 
relations during the colonial and postcolonial periods in Tanzania is necessary. ${ }^{4}$ Hundreds of years ago, Maa-speaking peoples migrated southwards into Southern Kenya and eventually Northern Tanzania, where they settled along the Rift Valley and began practising a range of different productive strategies, including pastoralism, agro-pastoralism, cultivation, and hunting and gathering. The term 'Maasai' was initially used to refer to a specific territory. By the early nineteenth century, those who are identified as 'the Maasai' today emerged as a distinct group embracing pastoralism as their primary mode of production, but it was not until the late 1870s, and then only after much debate among early Euro-American travellers, colonial administrators, and scholars, that the term was used to distinguish pastoralists from Maa-speakers pursuing other productive strategies. Maasai eventually came to refer to themselves as 'Maasai' in certain contexts (especially in their interactions with colonial administrators), but more often identified themselves by a range of names marking their clan, section, locality, or broader collectivities.

To exploit shifting and unpredictable micro-ecological conditions, Maasai practised a form of transhumant pastoralism whereby individual localities or sections (olosho, pl. iloshon) collectively demarcated available land into at least four different pasture types, each with its own rules of access and use: wet season grazing lands in which temporary rain pools and grasses were used; dry season grazing lands in more fertile areas near permanent water supplies; pastures near the homesteads for calves, sick animals and small stock; and the most fertile areas, which were used as drought reserves. ${ }^{5}$ Access to permanent and semi-permanent water resources was controlled by clans or sections, as were salt licks. The ability of Maasai to subsist primarily from livestock products (especially milk) depended to a great extent on their access to cultivated food products through relationships of trade, intermarriage, and stock-partnership with neighbouring cultivators. Some Maasai also farmed, and Maasai women gathered wild plants and grasses needed to supplement their food supplies, especially in times of drought. Maasai did not, however, hunt game for food, although wild animals such as lions were killed as necessary for the protection of people and homesteads.

Today, Maasai are a cultural minority in Tanzania, maintaining a language, dress, rituals, and customs that are distinct from the 'Swahili' majority who control the state apparatus. Intentional 'underdevelopment'

4. The following summary is drawn from the detailed history presented in Hodgson (2001). For early Maasai history, see Bernsten (1979, 1980), Sutton (1990, 1993), and Waller $(1979,1985)$. See Spear and Waller (1993) for diverse approaches to, and accounts of, the complex dynamics of identity among Maa-speakers.

5. For a comprehensive analysis of current range management and animal husbandry practices among Tanzanian Maasai, see Homewood and Rodgers (1991). 
by British colonizers, especially in terms of limited educational opportunities in Maasai areas, left most Maasai ill equipped at independence to fully participate in political rule and nation-building. The educated African elite who took power considered Maasai to be embarrassing relics of their 'primitive' past. They either ignored Maasai demands for 'development' and directed limited state resources to areas and people in the country they perceived as more 'progressive', or implemented brutal measures to coerce and force Maasai to assimilate to the dominant 'Swahili' culture. ${ }^{6}$ As a result, Maasai have become increasingly disenfranchised from economic opportunities and political power in Tanzania.

Within this context of political and economic marginalization, there has been a long history of land alienation in Tanzanian Maasailand, beginning with the formation of a Masai Reserve by the Germans in 1905. Eager to settle the fertile Maasai grazing lands between Mount Meru and Mount Kilimanjaro with Boer settlers, the Germans forcibly moved Maasai into a reserve south of what is now known as the Arusha-Moshi road. The Germans were, however, generally unsuccessful in restricting Maasai people and their livestock to the Reserve, especially when World War I (WWI) broke out and they had to direct their attention (and scarce personnel) elsewhere. Unimpeded, Maasai dispersed throughout the country in search of better lands, steady water supplies, and more advantageous living arrangements, such as proximity to cultivators with whom Maasai exchanged food.

Thus when the British assumed control of Tanganyika from the Germans after WWI, they encountered Maasai scattered throughout northern and central Tanganyika. Colonial administrators were disturbed by what they perceived as the dissolution of the renowned 'Maasai' and fearful of the threats posed to colonial control and order by the dispersal of these 'fierce', 'war-like' nomadic people. To contain the possible menace and restore 'the Maasai' to their reputed former glory, administrators resurrected the idea of the reserve to reunite and concentrate Maasai in a single, bounded area. After several years of planning and negotiations, the Masai Reserve was finally approved in 1922, and Maasai livestock-herders were once again forcibly relocated and confined. The boundaries were set to accommodate the interests of settlers, neighbouring administrators, and ease of demarcation, so that many permanent water supplies and dry season grazing areas were carefully excised from the reserve. Indeed, some settlers were allowed to remain on fertile ground in the reserve, farming small areas but profiting greatly from selling water and grazing rights to Maasai. ${ }^{7}$ The boundaries

6. These measures included refusing to allow men or women dressed in 'traditional' Maasai clothing to ride buses or enter towns.

7. Maasai living around Monduli, for example, paid one settler $£ 1000$ a year in 1930 for water rights to Lemisigie, the mountain stream which was the main permanent water source for the area (Webster, PC/NP to CS/Dar, 7 Mar. 1930, TNA 17/43). 
also excluded several important ceremonial sites, much to the consternation of some administrators.

Reserve boundaries were constantly disputed and disregarded by Maasai, who 'trespassed' in search of water, grazing, and the maintenance of important social networks. Administrators tried to regulate and control the movement of Maasai and their livestock, but often to little avail. Certain fertile areas of long-time Maasai occupation like Olmolog (also a ceremonial site) became areas of ongoing dispute between Maasai, administrators, and settlers. In the end, the reserve's borders, with some extensions and adjustments, came to form the boundary of Masai District (which has been subdivided several times since independence).

Land alienation by the government in the interests of settlers, non-Maasai cultivators, and the government itself continued throughout the colonial period. Much of the remaining fertile land, such as the Mondul mountain slopes, was alienated in favour of 'more productive' cultivators, both European and African. During the Second World War, other land was 'borrowed' by the government for such disastrous initiatives as the Northern Province Wheat Scheme, which destroyed over 20,000 acres of prime grazing land on the Ardai plains, and 'temporary' leases to settlers for war-time food production which were converted, in spite of Maasai protests, to long-term leases at the end of the war. In addition, the government sanctioned the large-scale immigration of Arusha (Maa-speaking agro-pastoralists) into Maasai areas to relieve pressure on increasingly scarce resources surrounding Mount Meru. ${ }^{8}$

Government-sanctioned land alienation and the immigration of other groups continued after independence. Many Maasai were forcibly relocated from their non-nucleated settlements into government-demarcated 'villages' during the 1970s, as part of then President Nyerere's Ujamaa policies. Although government 'villages' ignored and crosscut locality boundaries, thereby disrupting customary mechanisms for managing access to natural resources, the village boundaries were never firmly fixed. More importantly, they were never recognized by resident Maasai groups.

Land alienation has taken other forms as well. Most notably, Maasai have been repeatedly expelled from their land in the interests of wildlife conservation and tourism. Areas once used by Maasai, but now declared off limits to pastoralists and their livestock, include the Serengeti National Park, Tarangire National Park, and most recently the Mkomazi Game Reserve (Igoe and Brockington, 1999). Despite their long-term accommodation to living amidst, and sharing resources with, game, Maasai have been

8. Arusha had been moving into Maasai areas since at least the $1920 \mathrm{~s}$, but in much smaller numbers (Murrells, DO/MaD to PC/NP, 29 Jan. 1929, TNA 17/37). See Spear (1997) for detailed historical accounts of the Arusha expansions and migrations from their perspective. 
generally unable to fight misguided beliefs that the interests of humans and wildlife are incompatible, and have been forced to contend with a new 'reserve' system designed to protect wildlife. Moreover, in lucrative wildlife viewing areas such as the Ngorongoro Conservation Authority, resident Maasai who were desperate to feed their families were long prevented from pursuing small-scale farming. Another key source of land alienation, in Maasai areas as elsewhere, has been the creation of forest reserves, which place strict limitations on access to forest resources, even in times of drought.

In the mid-1980s, the process of land alienation (both legal and illegal) accelerated, as structural adjustment produced an influx of foreign capital for commercial farms, ranches, mining initiatives, and additional tourist accommodations. Large areas of Maasai grazing land were 'leased' for commercial farms and ranching operations, often by district and regional leaders and without the knowledge or agreement of local residents. To take but one example, in 1983 the regional government allocated 268,000 acres of land for the establishment of a cattle ranch by Tanzania Cattle Products, a company co-owned by Tanzanians and Italians. Not only did the large tract of land (a quarter of the total district acreage) contain essential minerals, but pastoralist communities had invested heavily in expanding the area's water infrastructure through the construction of boreholes (Ole Ndapa, 1994).

The big game hunting industry began a period of rapid expansion throughout the late 1980s and 1990s. Nshala (1999) reports that the number of hunting blocks increased from forty-seven in 1965 to 140 by 1997, with a parallel increase in the number of companies catering to the demands of tourist hunters from nine in 1984 to thirty-three in 1996. The clientele of these firms generated sizeable revenues - the equivalent of almost US\$9 million in the period 1997 to 1998 - for the Wildlife Division of the Ministry of Tourism and Natural Resources (Leader-Williams et al., 1996; TAHOA, 1998). Consequently, pressure on land surrounding national parks increased greatly.

A central issue in all of these examples of land alienation was the quality of the land being lost - most of these alternative land uses were concentrated in or around the most fertile dry-season grazing grounds upon which Maasai's transhumant agro-pastoralist system depended. Not only were Maasai denied access to the permanent grasses and water supplies necessary to sustain their livestock during the dry season, but these restrictions substantially increased pressure on their wet-season grazing grounds. Furthermore, the patchwork of excisions and reserves circumscribed both pastoralists' mobility and their flexibility in adapting to microecological changes in climate, soil condition, and pasture quality. Finally, the stereotype of Maasai as 'pure' pastoralists has served as a pretext for dispossessing them of some of their most prized farming areas, thereby eliminating an increasingly important strategy of economic diversification in many Maasai communities. 


\section{CONTEMPORARY DILEMMAS}

As a result of both the historical conflicts over land and the recent dramatic increases in expropriation, Maasai have felt their lands and livelihoods to be under increasing threat. In response, a series of mapping exercises and legal manoeuvres has been launched to identify and protect critical pastures. These initiatives originate from different quarters and address very different objectives. Indeed, they seem to have created some rather strange bedfellows, linking grassroots political actors with the state, and conservation NGOs with private sector actors. On the one hand, where successful, these new alliances would seem to suggest the potential of mapping exercises for bringing together conflicting parties. On the other, the involvement of these different sorts of actors underscores a tension that runs through many counter-mapping efforts regarding political intentions. The growing willingness on the part of centralized authorities to engage communities in conversations over resource management concerns is often accompanied by a fear that the political processes thus set in motion might run out of control. ${ }^{9}$ We return in our conclusion to the question of whether the 'community' mapping efforts described below actually 'counter' centralized political authority. We turn now to brief descriptions of four case studies, followed by a more detailed analysis of the broader issues they raise.

\section{The Village Registration Campaign}

In the mid-1980s, Maasai leaders approached the Arusha Diocesan Development Office (ADDO) to enlist the NGO's help in resolving a number of land tenure problems, including: a government proposal to eradicate 'customary' land tenure altogether; surreptitious land deals by corrupt village, district and other leaders taking advantage of the lack of officially demarcated boundaries; increasing encroachment by neighbouring groups who put land under cultivation without recognizing pastoralist land rights; and the destruction of trees and other resources through extensive charcoalmaking. With the financial assistance of the Ford Foundation and a number of other international donors, ADDO development agents worked with Maasai Catholic priests and community leaders to document the extent of legal and (especially) illegal land alienation in Maasai areas. Once the extent of land alienation was determined, this group then considered how best to protect the remaining lands held by Maasai groups.

Central to the ensuing debates was the problem of individual versus collective rights, an issue that was seen as being particularly contentious in

9. One conservation authority likens the inherent political risks of community mapping to 'the sorcerer's apprentice who enchants a broom so his work will be easier and is then dismayed to discover that the broom has taken on a life of its own' (Eghenter, 2000: iii). 
the context of both Maasai customary land use practices and national land laws. There were also concerns regarding the limited financial resources and the vast area under consideration (the three predominantly Maasai districts at the time encompassed approximately $64,000 \mathrm{~km}^{2}$ ). Eventually ADDO and the loose coalition of collaborating Maasai leaders decided to survey and demarcate Maasai lands within the national structure of government 'villages', vesting legal title to collectively held 'village' lands in each villagelevel government council (comprised at the time of both villager-elected and government-appointed members). Despite government resistance at all levels (in part because many government officials were themselves taking advantage of the lack of legal title in Maasai areas to directly and indirectly appropriate Maasai lands), but with generally enthusiastic community support, ADDO began to survey and title land parcels in the areas of greatest land pressure in Kiteto, Simanjiro and Monduli Districts. By 1993, some forty-five villages had initiated the registration process under ADDO's guidance, and an additional forty-five had been identified for inclusion in subsequent phases of the project (ADDO, 1993). The village registration campaign was eventually extended to several other parts of the country, often in connection with the establishment of community-based wildlife management areas (Kiwango, 1999).

\section{Community-Based Wildlife Management Areas}

In the early 1990s, a series of initiatives were undertaken to create communitymanaged wildlife and natural resource management areas in Tanzania. The principle adopted in the establishment of these reserves was that localized groups can and will manage natural resources effectively if they share directly in the profits such resources generate.

In 1991 and 1992, two tourism companies operating 'non-consumptive' safari camps in collaboration with local Maasai communities petitioned the Tanzanian Wildlife Division, which has jurisdiction over wildlife on lands outside the national park system, for the creation of community-based wildlife management areas adjacent to Serengeti and Tarangire national parks (Dorobo Safaris Ltd. and Olivers Camp, 1995). Three areas measuring $250 \mathrm{~km}^{2}, 120 \mathrm{~km}^{2}$ and $20 \mathrm{~km}^{2}$, respectively, were carved out of hunting blocks that were deemed incompatible with the wilderness camping, walking tours and bird watching safaris the companies promoted.

The Wildlife Division approved initial negotiations, and conditions of access to specific areas were laid out in detailed contracts between the companies and the communities. Adopting the premise that community residents hold inherent rights to their lands (a sharp contrast from the official position of the Wildlife Division), the companies agreed to pay for exclusive rights to use the reserve areas. Unlike fees collected from hunters operating in the target areas, which only filtered down to the community 
level in token amounts, funds generated by the 'non-consumptive' tour operators were more directly controlled by community groups, and were thus arguably of greater local benefit. These early efforts to share profits with community groups and thereby garner support for tourist ventures were quickly replicated by a number of other tour operators, especially those working in prime game viewing areas immediately adjacent to national park boundaries (Woien and Lama, 1999). The principle was also eventually adopted by a consortium of major donors including the African Wildlife Federation and USAID who saw this approach to community groups as the best way to promote a broad range of conservation objectives in northern Tanzania.

\section{The Buffer Zone Mapping Project}

The Tarangire Conservation Project (TCP) originated as a research programme devoted to the study of wildlife ecology on the eastern flank of Tarangire National Park in Tanzania. The participants in this project, which was funded by the European Union, were the Tanzania National Parks Authority (TANAPA - the parastatal responsible for managing the country's national park system), a research team from the University of Milan-Varese Branch in Italy, and the Italian NGO, OIKOS. The wildlife ecology component of the project consisted of tracking the migratory patterns of zebra, wildebeest, elephant, buffalo and other wild game through the use of radio collars and aerial photography. A team of American, Italian and Tanzanian experts used the data compiled via these methods to generate a complete Geographic Information System (GIS) database detailing wildlife movements between Tarangire and the Simanjiro plains - the end goal being strategies that would preserve corridors used by the wildlife in their seasonal migrations into and out of the park (TCP, 1996, 1998; cf. Otto et al., 1998).

As part of this effort, communities in Simanjiro were invited to help map community resources and add them to the database (TCP, 1996). This effort was conducted under the joint auspices of the TCP and a special initiative sponsored by TANAPA known as the 'Ujirani mwema', or 'good neighbourliness', programme (see Igoe, 2000). The objectives of the community mapping exercise included 'identif[ying] current or likely future areas where the greatest conflict between humans and wildlife can occur,' and 'provid[ing] local communities with an opportunity to highlight problems connected with the park' (University of Milan, 1994: 8). The outcome of the effort was to be a co-ordinated zoning system rationalizing land use in the Simanjiro buffer zone. Specifically, the community outreach programme was meant 'to identify feasible options for the reconciliation of conservation and development' and plans called for 'incorporat[ing] local indigenous technical knowledge and approaches to management [so] as to optimize the likelihood that they will be socially and culturally compatible and therefore sustainable' (University of Milan, 1994: 5). 
Although the outreach effort was subsequently met with considerable resistance on the part of Simanjiro residents (see further discussion below), the project nonetheless successfully generated a series of explicit maps documenting wildlife migratory patterns and human settlements in the Simanjiro plains area. The multi-year study resulted in detailed proposals for the establishment of additional wildlife management areas outside Tarangire Park (that is, for an extension of the protected area system), including recommended strategies for the use of these areas (TCP, 1998).

\section{The Pastoralist Reserve}

Over the past decade, several Maasai NGOs have been created in northern Tanzania to lobby for the protection of land rights, cultural preservation, and locally-defined development. ${ }^{10}$ At various times and in different forums, members of these NGOs and other Maasai activists have called for the creation of a new category of reserve land that would be preserved for the exclusive use of pastoralist groups. The formal recommendation adopted by participants in the fifth meeting of the Pastoralist Network in Tanzania (PANET) in 1994 provides an example of these initiatives:

Recommendation: PANET should support the declaration of certain districts/land units as
'pastoral areas'. Demarcation, allocation and titling of lands for pastoralists in perpetuity
should be promoted as a way to protect pastoral lands from land grabbing. Consideration
should be given to new institutional frameworks based on the traditional system, to facilitate
negotiation between villages and communities for sharing and co-management of range
resources. PANET should commission more studies on what institutional frameworks are
appropriate for different pastoral groups. (PANET, 1994: 6; cf. PANET, 1993: 7)

In particular, Maasai leaders have argued for state recognition of protected status for critical resources, including critical dry season grazing areas and strategic drought reserves. They have also advocated relaxing existing constraints on pastoralist access to protected areas in times of crisis: that is, to allow cattle into the parks on a special needs basis.

Actual implementation of these proposals has been quite isolated, often carried out on a village by village basis rather than on the grand, panpastoralist scale envisioned by some proponents. The community of Kitwai in southern Maasailand, for example, has sought to establish a pastoralist reserve through the use of local by-laws. These self-imposed rules (which required District Council approval) stipulate that the entire village should be recognized as a pastoralist reserve, prohibiting non-residents from cultivation altogether, and restricting local villagers to cultivation on subsistence plots no larger than a few acres. ${ }^{11}$ Other communities have achieved similar

10. For more information on these groups, see Hodgson (1999, nd); Igoe (1999, 2000); Neumann (1995).

11. Interview with James Kaharananga, by Richard Schroeder (7 July 2000, Arusha, Tanzania). 
results via less formal, customary zoning restrictions. The comparative rarity of the reserves notwithstanding, proposals for the establishment of pastoralist reserves continue to surface in debates within the pastoralist NGO community, and thus merit serious consideration as a counter-mapping focus in their own right.

\section{DISCUSSION}

Each of the four projects outlined above was ostensibly designed to help identify and clarify rights of access to community-based resources in a political ecological setting characterized by extreme land pressure. Each involved 'mapping' efforts - the delineation of boundaries and the classification of land and/or resources - designed to 'counter', or at least revise, some aspect of dominant, usually state-sanctioned land use practices and perceptions. While these efforts achieved varying degrees of success in attaining their counter-mapping objectives, none was free of controversy or difficulty. Indeed, each of these cases involved a series of complicated dilemmas.

The village registration efforts mounted by ADDO, for example, were clearly born out of political expediency. The activists and donors involved in the early stages of the project were uncomfortable with the idea of fixing community boundaries around corporate entities called 'villages' and registering these new units with the state. Maasai community representatives opted for this strategy anyway because they judged it to be their only means of preventing further land alienation under prevailing political economic circumstances. While the registration campaign was successful in protecting resources in some areas, three specific problems developed. The first involved the problem of erasure. Specifically, the focus on 'villages' obscured land use agreements already recognized by Maasai groups under customary land law. Existing divisions of land into pasture types (or farms) with complicated rules of access controlled and monitored by territorial sections (iloshon) and clans were ignored (and thereby undermined) in favour of the neat boundaries demanded by government surveyors and land registration offices.

The second problem was the question of resource access under the new system. The explicit focus on external territorial boundaries left somewhat unresolved the question of access to strategic resources contained within them such as water and salt licks. Once surveyed and bounded, access to these formerly communal resources could be denied, even to the residents of nearby villages. ${ }^{12}$ The net effect of the early registration efforts in many

12. Interview with Francis ole Ikayo, by Dorothy Hodgson (6 January 1998, Arusha, Tanzania); interview with Peter Toima, by Richard Schroeder (3 July 2000, Arusha, Tanzania). 
areas was that critically important reciprocal support mechanisms that have historically linked different Maasai groups in times of crisis were disrupted (Igoe and Brockington, 1999). More recently, the issue of resource access within village boundaries has taken precedence over the external boundary question in many areas. In the run up to national elections in 2001, Tanzania's ruling party pushed for the subdivision of larger villages in the interests of increasing party representation in district and regional assemblies. In this context, the question of which new village would retain control over resources such as water sources, schools, grass, livestock dips, cattle routes, wild animals and their habitats (a potential resource given the recent pattern of investment in the tourist sector), mountains/hills, salt licks, valuable stones/minerals, plants/trees (especially medicinal), and forests was hotly contested. ${ }^{13}$

The third difficulty with the registration efforts was the problem of exposure. By clarifying 'village' boundaries and consolidating legal control over land in the hands of village leaders, some of whom were not democratically elected, the process of land alienation was often accelerated. Village leaders could now 'sell' land that was legally demarcated, precisely because their knowledge of the extent of village claims had been enhanced through the registration process. Numerous complaints emerged in the aftermath of registration efforts about shady (if not always strictly illegal) land deals as urban elites, dishonest government officials and even nonTanzanian expatriates bribed or cajoled village chairs and council members to relinquish control of registered land. In sum, the village registration effort, which was designed to protect pastoralist resources and formalize common property rights to them, has in many respects been co-opted and converted into a semi-privatized resource management system dominated by corrupt village leaders.

The community wildlife and natural resource management areas were, by contrast, somewhat more successful in meeting the needs of Maasai communities interested in protecting community claims. Recognizing that community wildlife reserves could generate additional income to fund village-level development projects, and judging the terms of the land setaside agreements to be favourable, these communities struck a number of deals with tourist companies offering village territory for game viewing camps and lodges in exchange for a small share of the profits generated by these concerns. The proliferation of such reserves, however, has threatened the power of the Wildlife Division (which granted the original leases), and most particularly the revenue it regularly receives from hunting fees (Schroeder, nd). The reserves have also directly conflicted with the desires and practices of hunting companies, which have resisted any form of

13. Interview with Alais Morindat, by Richard Schroeder (20 July 2000, Usa River, Tanzania). 
restriction on their access to game within their designated hunting blocks. Not only have these firms lobbied the Wildlife Division to contest the legality of the community reserves, but in several cases they have attempted to directly intimidate tour operators and their clients in the bush. Furthermore, the deliberately small-scale, community-based wildlife management area projects have proved relatively weak when confronted with heavily capitalized competing claims to the reserve areas: one reserve was at least temporarily swept off the land altogether when a wealthy investor from the United Arab Emirates paid the government for a huge private hunting block, despite substantial community outrage (Honey, 1999). Finally, exclusivity itself became an issue among the tour operators. Some companies strongly disagreed with the premiss that formerly 'open access' land should be reserved exclusively for the use of any single firm at the expense of others. The effect of this disagreement has been to undermine the political and economic solidarity that small-scale tour operators might otherwise share, thereby weakening their capacity to effectively challenge the status quo.

From the beginning, the buffer zone mapping effort of the Tarangire Conservation Project was extremely contentious. Anthropologist James Igoe describes some of the project activities that were most objectionable to area residents:

The social science component of the project consisted of participatory village resource mapping with the use of remote sensing equipment. The project vehicles were marked with a large TANAPA logo. The mapping teams were frequently escorted by an armed TANAPA ranger. A project airplane was spotted regularly flying along the borders of the park. Although this plane was tracking wildlife, TCP staff never bothered to inform local people of this.

In the context of their previous experiences with Tarangire [National Park], local people invested even the most mundane aspects of the TCP with sinister qualities. 'If the project truly sought to benefit local communities, then why was it called the Tarangire Conservation Project and not the Simanjiro Conservation Project?' If TANAPA is so committed to Community Conservation, then why does their logo feature a gazelle instead of a person? (Igoe, 2000: 336; see also Igoe, 1999)

Peter Toima, a Maasai activist working in the Simanjiro area, amplifies these concerns. According to Toima, community residents also wanted to know why the project wanted to map Maasai bomas (homesteads) as part of its demographic survey. ${ }^{14}$ Belying a shrewd appreciation of the dangers of 'fixed' cartographic knowledge, Simanjiro residents argued that bomas are not in fact permanent structures, and should therefore not be represented as such on maps. Their fear was that if the project continued to map bomas, this information could be used to force residents to keep their bomas in fixed positions, which would mark a serious challenge to their semi-transhumant pastoralist system. Ultimately, representatives of one of the more militant

14. Interview with Peter Toima, by Richard Schroeder (3 July 2000, Arusha, Tanzania). 
Maasai NGOs active in the Simanjiro area successfully mobilized area residents to block the project through non-compliance in several villages. The irony in all of this is that the community outreach programme organized by TANAPA in connection with the TCP was the only project component directly concerned with community needs. Yet it became the object of community opposition, while the pure wildlife ecology components of the project, which could yet produce more conflict over expansion into Simanjiro, continue. This case demonstrates above all that the long history of alienation experienced by Maasai in Ngorongoro, Mkomazi, Tarangire, Serengeti, and similar richly endowed territories in Kenya cannot simply be undone over night.

Finally, the pastoralist reserve initiative and similar proposals, while still largely in the conceptual stage, pose tremendously complex political problems. On the one hand, some sort of formal protection for pastoralist rights would seem warranted on the grounds of environmental justice. There is also a case to be made on the grounds of political expediency. Indeed, when one of the proponents of a new pastoralist reserve was asked what it meant to draw hard boundaries around key water and land resources in a pastoralist economy premised on mobility, he gave a telling response: 'People are drawing hard boundaries around parks and farms and hunting blocks all around us. If we don't make the hard choices now about where to draw boundaries around our own resources, those people are going to draw them for us. ${ }^{15}$ While we find these arguments compelling, they do little to address several crucial counter-mapping dilemmas. In particular, the proposals under development tend to be rather vague as to where such reserves might be located, and what the precise nature of rights to the reserve should be. The latter concern is particularly troubling. One of the more recent proposals ostensibly calls for land to be set aside for the exclusive use of 'pastoralists'. Does this mean that Maasai and other pastoralist groups who also practise agriculture will be excluded from reserve territories? The proposals under discussion also seemingly ignore crucial historical precedents for mapping Maasai territory. If a reserve is created, will pastoralists in general and Maasai in particular be restricted to that area? What is to prevent the new pastoralist reserve from taking on the connotations of the Masai Reserve created during the colonial period?

Maasai observers are of different opinions as to the value of the proposed pastoralist reserves, but they are nearly unanimous in their scepticism regarding their political feasibility. Reacting to the description of the community by-laws promoted by the residents of Kitwai described above, one Maasai activist called it:

15. Interview with Francis ole Ikayo, by Richard Schroeder (13 January 1998, Arusha, Tanzania). 
A good example of a great idea being implemented in a very wrong place. Kitwai is among the poorest and most ecologically/economically marginal of all the Maasai areas. Hence, there is very little there to protect in the first place. I would like to see them try and pass such by-laws in a well-endowed community like Emairete, Enguike, Manyara, Makuyuni, or Lendikenya. In such communities where the returns are potentially much greater from the creation of a reserve, the pressures by external forces are also greater, so the prospects of actually making a pastoralist reserve a reality are very slim. ${ }^{16}$

Another opined that government policies would never allow such an arrangement to go forward, and argued that the Maasai community had much more pressing business to attend to than pursuing such empty objectives: 'We are part of the nation [Tanzania]; we do not live on an island'. ${ }^{17}$

\section{COUNTER-MAPPING LESSONS}

In this article, we have briefly discussed four case studies that, in our estimation, display many of the quintessential dilemmas confronted by would-be counter-mappers the world over. It has to be acknowledged, though, that the responses Tanzanian activists choose to make to these 'dilemmas', or, indeed, the extent to which these problems are seen as 'dilemmas' at all, will hinge greatly on a set of normative political considerations that are not necessarily ours to determine. Maps generated by counter-mappers and the legal and extra-legal strategies that typically accompany them are explicitly political in origin and intent, and the actors involved will inevitably assess the fallout they generate on similar terms.

This is not to say, however, that there are no lessons to be drawn from these cases. First of all, while all of the mapping efforts described above were born of complex and highly localized circumstances, it is important to recognize that they also represent much broader trends in environmental management (Schroeder, 1999a) - including well publicized initiatives to territorialize community lands (village registration campaign), privatize natural resources (community wildlife management areas), integrate conservation with development (Tarangire buffer zone mapping project), and protect indigenous land rights (pastoralist reserves). In this regard, it is somewhat difficult to separate out the politics of popular resource mapping exercises, per se, from the practical and political ecological problems associated with the trends they represent.

A second point to emerge from the brief case histories is that countermapping is neither a panacea nor a quick fix for resource management problems. In particular, where long-term, deep-seated animosities exist between the state and local resource users, such as in Tanzania, similarly

16. Interview with anonymous research informant, by Richard Schroeder (20 July 2000).

17. Interview with second anonymous research informant, by Richard Schroeder (3 July 2000). 
long-term, good-faith engagements will be required before more productive and equitable solutions to land management conflicts can be found. Clearly, complex political tensions surrounding land rights such as those that prevail in northern Tanzania defy representation via conventional cartographic techniques. Moreover, the evidence provided by these case studies suggests that mapping exercises must be accompanied by well-conceived legal and political strategies if they are to achieve their full potential. If the mapping of community boundaries through the village registration campaign facilitates land sales by corrupt individuals, the solution is not to give up village mapping, but to create mechanisms to deal with corrupt leaders and illegal sales. If maps create boundaries disrupting reciprocal relationships between and among communities, a corresponding effort should be made to gather knowledge about the history and nature of these resource-sharing mechanisms so that they might be codified within resource management plans. The drafting of by-laws in support of community-based wildlife management areas is a case in point (cf. Dorobo Safaris, 1997; Nshala et al., 1999). In the absence of such parallel efforts in the legal and political domains, the mapping process itself is little more than a sterile exercise.

The third point is that the community resource mapping initiatives we have discussed have all been premised on different notions of 'community' with different implications (see Brosius et al., 1998). Mapping decisions frequently promote and produce particular identities. In this sense, the drawing of cartographic boundaries is as much a cultural exercise as a political-economic one. As Kosek cogently argues:

a community does not just make a map, but rather... a map helps to make a community, both reflecting and producing social relations. The process of mapping helps naturalize and communicate a dominant idea of who belongs within particular boundaries and who does not, who may make decisions on behalf of the community and who may not. (Kosek, 1998: 5)

In the village registration efforts described above, communities were intentionally equated with 'villages', a particular legal jurisdictional entity with special salience in Tanzania given the history of forced villagization under the 'Ujamaa' policies of the post-independence socialist government. In the contemporary setting, the registration of 'villages' has meant the conferring of special rights on village leaders, who have frequently profited greatly from this arrangement. In the case of both the community wildlife reserves and buffer zone projects, the 'community' is the 'local community', residents of villages located in park buffer zones or adjacent to areas with a distinctive scenic or wilderness character. The residents of these communities are simultaneously those who have suffered the greatest losses due to dispossession related to conservation efforts in the past, and those who stand to gain the most from revenue sharing agreements with tour operators and park authorities in the present. Working with these groups on communal projects is thus fraught with tension given the historical precedents. 
In the case of the pastoralist reserve, the community in question is the community of all pastoralists. This aspatial, pan-pastoralist focus conflates cultural identity with a particular mode of production (being Maasai). While it simultaneously preserves and restricts access, it also determines cultural identity on a very pragmatic political level. It should be evident from this discussion that the challenges inherent in mobilizing these different 'communities' for different purposes are not identical.

The latter point leads to our final set of observations. Mobilizing a community to support a conservation effort is not the same as mobilizing it around claims for greater economic security or broader territorial control. Although conservation related mapping exercises may involve extensive community participation, they may not, strictly speaking, involve a countermapping initiative at all. Our reading of these cases suggests, accordingly, that there is a need to draw a distinction between the Tarangire Conservation Project, which involved 'community' mapping without mounting a challenge to centralized authority, and the other three cases we have discussed, which we would consider 'counter-mapping' in the strictest sense of the term. The village registration projects, while fraught with difficulties, were clearly designed to counter the loss of community lands to outsiders. Similarly, the creation of community-based wildlife management areas explicitly challenged the Wildlife Division's prerogatives over wildlife resources outside national parks. And the exclusive reserve concept articulated by pastoralist groups makes a direct counter-claim against other forms of spatial reserve already inscribed on the Tanzanian landscape. At an abstract level, these cases strongly suggest a need to carefully consider the structural positions of the different agencies involved in the mapping efforts, and the alliances and antagonisms between them. Can communities strike an effective counter-mapping agreement with the state, with one branch of the state against another, with business concerns, with conservationists? Can an effective alliance be struck on the basis of essentialist identity politics centred on ethnicity or some other form of social grouping? What precisely is being countered in the emerging counter-mapping movement, and how can its objectives be most effectively achieved without compromising parallel concerns for environmental justice? Clear answers to these kinds of questions are critical if the political potential of counter-mapping efforts is to be fully realized.

\section{REFERENCES}

ADDO (Arusha Diocesan Development Organization) (1993) 'Two and a Half Years Summary Report, 1991-June 1993.' Arusha: ADDO.

Arvelo-Jiménez, N. and K. Conn (1995) 'The Ye'kuana Self-Demarcation Process', Cultural Survival Quarterly 18(4): 40-2.

Bernsten, J. (1979) 'Pastoralism, Raiding and Prophets: Maasailand in the Nineteenth Century'. $\mathrm{PhD}$ dissertation, University of Wisconsin-Madison. 
Bernsten, J, (1980) 'The Enemy is Us: Eponymy in the Historiography of the Maasai', History in Africa 7: 1-21.

Brosius, J. P., A. L. Tsing, and C. Zerner (1998) 'Representing Communities: Histories and Policies of Community-Based Natural Resource Management', Society and Natural Resources 11(2): 157-68.

Dorobo Safaris (1997) 'Guidelines for Facilitating Village Based Planning and Management of Land Resources.' Unpublished manuscript.

Dorobo Tours and Safaris Ltd. and Oliver's Camp (1995) 'Potential Models for CommunityBased Conservation Among Pastoral Communities Adjacent to Protected Areas in Northern Tanzania', in N. Leader-Williams, J. A. Kayera and G. L. Overton (eds) Community-Based Conservation in Tanzania, pp. 100-6. Dar es Salaam, Tanzania: Department of Wildlife/ African Wildlife Federation/World Wildlife Fund.

Eghenter, C. (2000) 'Mapping Peoples' Forests: The Role of Mapping in Planning CommunityBased Management of Conservation Areas in Indonesia', Peoples, Forests and Reefs Program Discussion Paper Series. Washington, DC: Biodiversity Support Program.

Fox, J. (1998) 'Mapping the Commons: The Social Context of Spatial Information Technologies', The Common Property Resource Digest 45: 1-4.

Gonzalez, N., F. Herrera and M. Chapin (1995) 'Ethnocartography in the Darien', Cultural Survival Quarterly 18(4): 31-3.

Harris, T., D. Weiner, T. Warner, and R. Levin (1995) 'Pursuing Social Goals Through Participatory GIS: Redressing South Africa's Historical Political Ecology', in J. Pickles (ed.) Ground Truth: The Social Implications of Geographic Information Systems, pp. 196-222. New York: Guilford Press.

Hodgson, D. L. (1999) 'Critical Interventions: Dilemmas of Accountability in Contemporary Ethnographic Research', Identities 6(2/3): 201-24.

Hodgson, D. L. (2001) Once Intrepid Warriors: Gender, Ethnicity and the Cultural Politics of Maasai Development. Bloomington: Indiana University Press.

Hodgson, D. L. (nd) 'Rethinking Indigenous Development'. Unpublished manuscript.

Homewood, K. and W. Rodgers (1991) Maasailand Ecology: Pastoralist Development and Wildlife Conservation in Ngorongoro, Tanzania. Cambridge: Cambridge University Press.

Honey, M. (1999) 'Tanzania: Whose Eden Is It?' Ecotourism and Sustainable Development: Who Owns Paradise. Washington, DC: Island Press.

Hughes, D. (1999) 'Mapping the Hinterland: Land Rights, Timber, and Territorial Politics in Mozambique'. Policy Paper no. 44. Berkeley, CA: Institute on Global Conflict and Cooperation, University of California.

Igoe, J. (1999) 'Roadblocks to Community Conservation in Tanzania: A Case Study from Simanjiro District', African Studies Center Working Paper no. 218. Boston, MA: Boston University.

Igoe, J. (2000) 'Ethnicity, Civil Society, and the Tanzanian Pastoral NGO Movement: The Continuities and Discontinuities of Liberalized Development'. PhD dissertation, Department of Anthropology, Boston University.

Igoe, J. and D. Brockington (1999) Pastoral Land Tenure and Community Conservation: A Case Study from North East Tanzania. London: IIED.

Kiwango, E. (1999) 'Assessment of Community-Based Natural Resource Management in Tanzania: MBOMPIA Project, Idodi and Pawaga Divisions, Iringa Region and Selous Conservation Project, Songea and Morogoro Districts, Ruvuma and Morogoro Regions, Tanzania.' Dar es Salaam: USAID/EPIQ.

Kosek, J. (1998) 'Mapping Politics', The Common Property Resource Digest 45: 4-6.

Leader-Williams, N., J. A. Kayera and G. L. Overton (eds) (1996) Tourist Hunting in Tanzania. Gland, Switzerland and Cambridge, UK: IUCN.

Maantay, J. (1996) 'Bringing Mapping (and Power) to the People: Using "Counter-Mapping" to Assess, Analyze, Challenge and Change Environmental Social and Health Conditions in the South Bronx, New York'. Unpublished manuscript.

Neumann, R. P. (1995) 'Local Challenges to Global Agenda: Conservation, Economic Liberalization and the Pastoralists' Rights Movement in Tanzania', Antipode 27(4): 363-82. 
Nietschmann, B. (1995) 'Defending the Miskito Reefs with Maps and GPS', Cultural Survival Quarterly 18(4): 34-7.

Nshala, R. (1999) 'Granting Hunting Blocks in Tanzania: The Need for Reform.' Policy Brief no. 5. Dar es Salaam: Lawyer's Environmental Action Team (LEAT).

Nshala, R., D. Ngoitiko, and B. Gardner (1999) Natural Resource Management By-Laws. Dar es Salaam: USAID.

Ole Ndapa, M. H. (1994) 'Displacement and Marginalization: A Case Study of Tanzanian Cattle Products in Simanjiro District.' Summary published in the report of the Second Maa Conference on Culture and Development: Environment and Sustainable Pastoral Development. Arusha, Tanzania.

Otto, J., B. Kamara and T. A. Lissu (1998) 'Closing Corridors: Impacts of Policy, Privatization and Practice on Wildlife Movements in the Tarangire-Lake Manyara Area'. Dar es Salaam: USAID/EPIQ.

Pastoral Network of Tanzania (PANET) (1993) Newsletter of the Pastoral Network of Tanzania, Issue 4.

Pastoral Network of Tanzania (PANET) (1994) Newsletter of the Pastoral Network of Tanzania, Issue 5.

Peluso, N. L. (1995) 'Whose Woods are These? Counter-Mapping Forest Territories in Kalimantan, Indonesia', Antipode 27(4): 383-406.

Poole, P. (ed.) (1995a) 'Geomatics: Who Needs It?', Cultural Survival Quarterly 18(4): 1-77.

Poole, P. (1995b) Indigenous Peoples, Mapping and Biodiversity Conservation: An Analysis of Current Activities and Opportunities for Applying Geomatics Technologies. Washington, DC: Biodiversity Support Program.

Rocheleau, D. (1997) 'Musings on Mapping Against Power: Comments, Questions and Selected Examples', Paper presented at the Ford Foundation-sponsored conference, 'Representing Communities: Histories and Politics of Community-Based Resource Management'. Helen, Georgia.

Rocheleau, D. and D. Edmunds (1997) 'Women, Men and Trees: Gender, Power and Property in Forest and Agrarian Landscapes', World Development 25(8): 1351-71.

Rocheleau, D., B. Thomas-Slayter, and D. Edmunds (1995) 'Gendered Resource Mapping: Focusing on Women's Spaces in the Landscape', Cultural Survival Quarterly 18(4): $62-8$.

Rundstrom, R. A. (1995) 'GIS, Indigenous Peoples, and Epistemological Diversity', Cartography and Geographic Information Systems 22(1): 45-57.

Schroeder, R. A. (1999a) 'Geographies of Environmental Intervention in Africa', Progress in Human Geography 23(3): 359-78.

Schroeder, R. A. (1999b) Shady Practices: Agroforestry and Gender Conflict in The Gambia. Berkeley, CA: University of California Press.

Schroeder, R. A. (nd) 'Debating Distributive Environmental Justice: The Politics of Sharing Wildlife Wealth in Tanzania.' Unpublished manuscript.

Sirait, M., S. Prasodjo, N. Podger, A. Flavelle and J. Fox (1994) 'Mapping Customary Land in East Kalimantan, Indonesia: A Tool for Forest Management', Ambio 23(7): 411-17.

Sparke, M. (1998) 'A Map that Roared and an Original Atlas: Canada, Cartography, and the Narration of Nation,' Annals of the Association of American Geographers 88(3): 463-95.

Spear, T. (1997) Mountain Farmers: Moral Economies of Land and Agricultural Development in Arusha and Meru. London: James Currey; Berkeley, CA: University of California Press.

Spear, T. and R. Waller (eds) (1993) Being Maasai: Ethnicity and Identity in East Africa. London: James Currey.

St. Martin, K. (2001) 'Making Space for Community Resource Management in Fisheries', Annals of the Association of American Geographers 91(1): 122-42.

Sutton, J. (1990) A Thousand Years in East Africa. Nairobi: British Institute in Eastern Africa. Sutton, J. (1993) 'Becoming Maasailand' in T. Spear and R. Waller (eds) Being Maasai: Ethnicity and Identity in East Africa, pp. 38-60. London: James Currey. 
TAHOA (Tanzania Hunting Operators Association) (1998) 'A National and Global Perspective on the Tourist Hunting Industry in Tanzania: The Past, The Present, The Future and its Role in National Development'. Dar es Salaam: TAHOA.

TCP (Tarangire Conservation Project) (1996) 'Analysis of Migratory Movements of Large Mammals and their Interactions with Human Activities in the Tarangire Area (Tanzania) as a Contribution to a Conservation and Sustainable Development Strategy — Interim Report, Annexes'. Report to the European Commission Directorate General for Development.

TCP (Tarangire Conservation Project) (1998) 'Analysis of Migratory Movements of Large Mammals and their Interactions with Human Activities in the Tarangire Area (Tanzania) as a Contribution to a Conservation and Sustainable Development Strategy - Final Report, Appendices'. Report to the European Commission Directorate General for Development.

University of Milan (1994) 'Analysis of Migratory Movements of Large Mammals and their Interactions with Human Activities in the Tarangire Area (Tanzania) as a Contribution to a Conservation and Sustainable Development Strategy'. Financing proposal submitted to the European Commission by the Zoological Museum of the Department of Biology of the University of Milan.

Waller, R. (1979) 'The Lords of East Africa: The Maasai in the Mid-Nineteenth Century'. PhD dissertation, Cambridge University.

Waller, R. (1985) 'Economic and Social Relations in the Central Rift Valley: The Maa Speakers and their Neighbours in the Nineteenth Century', in B. Ogot (ed.) Kenya in the Nineteenth Century (Hadith 8), pp. 83-151. Nairobi: Anyange Press.

Walker, P. A. and P. E. Peters (2001) 'Maps, Metaphors, and Meanings: Boundary Struggles and Village Forest Use on Private and State Land in Malawi', Society and Natural Resources 14(5): 411-24.

Woien, H. and L. Lama (1999) Market Commerce as Wildlife Protector? Commercial Incentives in Community Conservation in Tanzania's Northern Rangelands. London: IIED.

Dorothy L. Hodgson is an Associate Professsor in the Department of Anthropology at Rutgers, The State University of New Jersey (131 George Street, New Brunswick, NJ 08901-1414, USA. e-mail: dhodgson@rci.rutgers.edu). She has carried out ethnographic and historical research on issues of gender and power, ethnicity, the cultural politics of development, and the missionary encounter, primarily among Maasai in Tanzania since 1985. Richard A. Schroeder is an Associate Professor in the Department of Geography at Rutgers, The State University of New Jersey (54 Joyce Kilmer Avenue, Piscataway, NJ 08854-8054, USA. e-mail: rschroed@rci.rutgers.edu). He has conducted research in Nigeria, The Gambia and Tanzania on gender, forms of environmental intervention and the political ecology of forestry, wildlife management, and irrigated agricultural systems. 